\title{
Penggunaan Model UTAUT2 Untuk Memahami Persepsi Pengguna Aplikasi G-Meet
}

\author{
Eka Herdit Juningsih ${ }^{1}$, Faruq Aziz ${ }^{2}$, Dinar Ismunandar ${ }^{3}$, Fajar Sarasati ${ }^{4}$, Irmawati $^{5}$, Yanto $^{6}$ \\ 1,2,3,5,6 IImu Komputer, STMIK Nusa Mandiri Jakarta \\ ${ }^{4}$ Sistem Informasi, STMIK Nusa Mandiri Jakarta \\ Email:114002418@nusamandiri.ac.id, ${ }^{2} 14002420 @ n u s a m a n d i r i . a c . i d$, \\ 314002421@nusamandiri.ac.id, 4Fajar.fss@nusamandiri.ac.id, 514002419@nusamandiri.ac.id, \\ 614002423@nusamandiri,ac,id
}

\begin{abstract}
Abstrak: Di era pandemi saat ini proses belajar mengajar dilakukan secara online dengan memanfaatkan aplikasi virtual, salah satunya yaitu G-Meet. Untuk memahami presepsi pengguna aplikasi G-Meet dalam penelitian ini menggunakan model UTAUT2. UTAUT2 merupakan pengembangan dari model UTAUT yang dilakukan oleh Venkates. Variabel yang ada pada UTAUT2 ini ialah ekspektasi kinerja, ekspektasi usaha, pengaruh sosial, kondisi fasilitas, motivasi hedonis, nilai harga, dan kebiasaan. Dari data yang dihasilkan terdapat 125 responden yang telah mengisi kuesioner dengan pertanyaan yang diajukan sebanyak 27 pertanyaan. Populasi dari penelitian ini adalah mahasiswa STIMIK Nusa Mandiri Jakarta. Dan untuk sampel yang ditentukan yaitu sebanyak 125 responden dari jumlah responden yang telah mengisi kuesioner. Dalam mengolah data penelitian pada penelitian ini menggunakan smartPLS 3, untuk mengetahui tingkat kevalidan dan kereabilitasan akan suatu data yang diperoleh. Hasil dari penelitian ini menujukkan bahwa dari delapan hipotesis yang diusulkan tiga hipotesis dinyatakan tidak signifikan karena pada nilai t-statistic kurang dari 1,96 dan untuk lima hipotesis lain dapat diterima.
\end{abstract}

\section{Kata kunci: UTAUT2, G-Meet, Pembelajaran Daring}

\begin{abstract}
In the current pandemic era, the teaching and learning process is carried out online by utilizing virtual applications, one of which is G-Meet. To understand the perceptions of users of the G-Meet application in this study using the UTAUT2 model. UTAUT2 is a development of the UTAUT model carried out by Venkates. The variables in UTAUT2 are performance expectations, business expectations, social influences, facility conditions, hedonic motivation, price values, and habits. From the resulting data, there are 125 respondents who have filled out a questionnaire with 27 questions. The population of this study were students of STIMIK Nusa Mandiri Jakarta. And for the specified sample, as many as 125 respondents from the number of respondents who have filled out the questionnaire. In processing research data in this study using SmartPLS 3, to determine the level of validity and reliability of the data obtained. The results of this study indicate that of the eight proposed hypotheses, three hypotheses are declared insignificant because the $t$-statistic value is less than 1.96 and the other five hypotheses can be accepted.
\end{abstract}

Keywords: UTAUT2, G-Meet, Online Learning

This is an open access article distributed under the Creative Commons Attribution License, which permits unrestricted use, distribution, and reproduction in any medium, provided the original work is properly cited. O2019 by author and IJSE-Indonesian Journal on Software Engineering.

\section{PENDAHULUAN}

Infeksi COVID-19 yang disebabkan oleh virus corona merupakan suatu pandemik baru yang dapat menular melalui penyebaran antar manusia yang sangat cepat (Kurniawan, Prabowo, \& Falahudin, 2020). Pandemi COVID-19 yang terjadi di Indonesia saat ini masih belum mengalami penurunan. Sehingga pemerintah masih tetap mengeluarkan kebijakan kepada masyarakat Indonesia untuk selalu tetap di rumah. Dengan cara tidak berkerumun, tetap melakukan pembatasan sosial (social distancing) dan tetap menjaga jarak fisik (physical distancing), serta memakai masker dan selalu mencuci tangan dengan benar (Sadikin \& Hamidah, 2020). Sebagai salah satu upaya untuk mencegah terpaparnya virus COVID-19, Pemerintah pusat telah mengeluarkan kebijakan untuk meliburkan seluruh lembaga pendidikan tak terkecuali dengan 
perguruan tinggi. Hal ini dilakukan untuk mengantisipasi menyebarnya virus corona semakin luas. Salah satu kebijakan di bidang pendidikan yang diambil pemerintah dalam menghadapi virus corona ini adalah belajar secara daring atau online (Riadi, Normelani, Efendi, Safitri, \& Tsabita, 2020). Dengan demikian proses pembelajaran pun harus menyesuaikan dengan keadaan tersebut (Rustaman, 2020).

Oleh karena itu, terdapat beberapa media pembelajaran yang dapat digunakan untuk proses belajar mengajar di era pandemi saat ini, diantaranya adalah virtual class dan video conference. Salah satu inovasi yang dapat dijadikan alternatif pada pembelajaran daring di era pandemik saat ini adalah pembelajaran Individual Number Head berbasis Google Meet (Fauzi \& Lestari, n.d.). Google Meet bisa menjadi media alternatif untuk proses belajar mengajar (Sawitri, 2020). Hal ini menjadikan mahasiswa di STMIK Nusa Mandiri Jakarta memakai aplikasi google meet pada pembelajaran daring. Selain karena adanya himbauan dari pemerintah yang menganjurkan untuk memakai aplikasi berupa video conference sebagai media daring, aplikasi tersebut juga sangat efektif untuk digunakan di masa pandemi saat ini.

Berbagai macam model penelitian telah dikembangkan untuk menjelaskan faktor-faktor yang memengaruhi minat dan penggunaan suatu sistem teknologi. Salah satu yang terbaru adalah model Unified Theory of Acceptance and Use of Technology (UTAUT) (Udayana, 2017). UTAUT merupakan sebuah model untuk menjelaskan perilaku pengguna terhadap teknologi informasi (Auliya, 2018). Model ini merupakan kombinasi dari delapan model yang telah berhasil dikembangkan sebelumnya (Narayana, 2019). Kemudian Venkates juga mengembangkan metode UTAUT dengan nama UTAUT2. Unified Theory of Acceptance and Use of Technology 2 (UTAUT2) merupakan pengembangan dari model UTAUT yang dilakukan oleh Venkates (Afiana, Subarkah, \& Hidayat, 2019). Model UTAUT memilki empat konstruk yang mempengaruhi niat perilaku untuk menggunakan teknologi yaitu : harapan kinerja (performance expectancy), harapan usaha (effort expectancy), pengaruh sosial (social influence), kondisi fasilitas (facilitating conditions) (Handayani \& Sudiana, 2017) terhadap niat (behavior intention) untuk penerimaan teknologi (use technology). Sampai saat ini, UTAUT2 menambahkan tiga konstruk baru yang ditambahkan pada UTAUT lama yaitu: motivasi hedonis (hedonic motivation), nilai harga (price value), dan kebiasaan (habit) (Mahande, 2018).

Pengukuran presepsi terhadap niat suatu aplikasi yang menggunakan metode UTAUT2 telah dlakukan dalam judul Analisis Pengaruh Penggunaan Tcash Menggunakan Unified Theory Of Acceptance And Use Of Technology 2 (UTAUT2) Studi Pada Mahasiswa Pengguna Tcash, hasil analisis menyatakan variabel facilitating condition, habit dan behavioral intention dalam penelitian ini terbukti berpengaruh signifikan terhadap use behavior mahasiswa Universitas Telkom menggunakan TCash. Jadi variabel tersebut yang mempengaruhi secara langsung use behavior mahasiswa, pengguna TCash di Universitas Telkom (Radiansyah \& Ariyanti, 2017). Pada penelitian yang lain dengan judul Penerapan Model UTAUT2 Untuk Mengevaluasi Aplikasi Ruang Guru, hasil yang didapat yaitu diperoleh variabel yang mempengaruhi yaitu ekspektasi kinerja, ekpektasi usaha, faktor sosial, kondisi yang memfasilitasi, motivasi hedonis, nilai harga, kebiasaan, dan kondisi yang memfasilitasi dimoderasi oleh umur (Haris, WA, \& Nasiri, 2019). Penelitian selanjutnya yang menggunakan metode UTAUT2 dengan judul Penerimaan Pengguna E-Wallet Menggunakan UTAUT2 (Studi Kasus), Hasilnya adalah dari dua belas hipotesis yang diusulkan, tiga hipotesis dinyatakan tidak signifikan dan ditolak karena nilai path coefficient dan t-test dari hipotesis tersebut (performance expectancy, hedonic motivation, dan price value) kurang dari 0,1 dan 1,96, sedangkan sembilan hipotesis lainnya dinyatakan signifikan dan diterima (Muhammad Taufik Hidayat, Qurrotul Aini, \& Elvi Fetrina, 2020). Dilihat dari penelitian sebelumnya, diharapkan penelitian ini dapat memberikan dampak yang positif bagi pengguna google meet dengan menggunakan model UTAUT2.

\section{METODE PENELITIAN}

Penelitian ini menggunakan data primer dengan penyebaran kuesioner menggunakan google form sebagai penilaian terhadap presepsi penggunaan aplikasi. Berdasarkan pemodelan UTAUT2, terdapat tujuh konstruk yang selanjutnya akan dipakai sebagai variabel bebas (independent). Diantarnya yaitu harapan kinerja (performance expectancy), harapan usaha (effort expectancy), pengaruh sosial (social influence), kondisi fasilitas (facilitating conditions), motivasi hedonis (hedonic motivation), nilai harga (price value), dan kebiasaan (habit). Sementara minat pengguna (behavioral intention) dan perilaku pengguna (use behavior) sebagai variabel terikat 
(dependen). Dan dimoderasi oleh faktor umur, jenis kelamin dan profesi. Berikut adalah model UTAUT2 yang terdapat pada gambar 1.

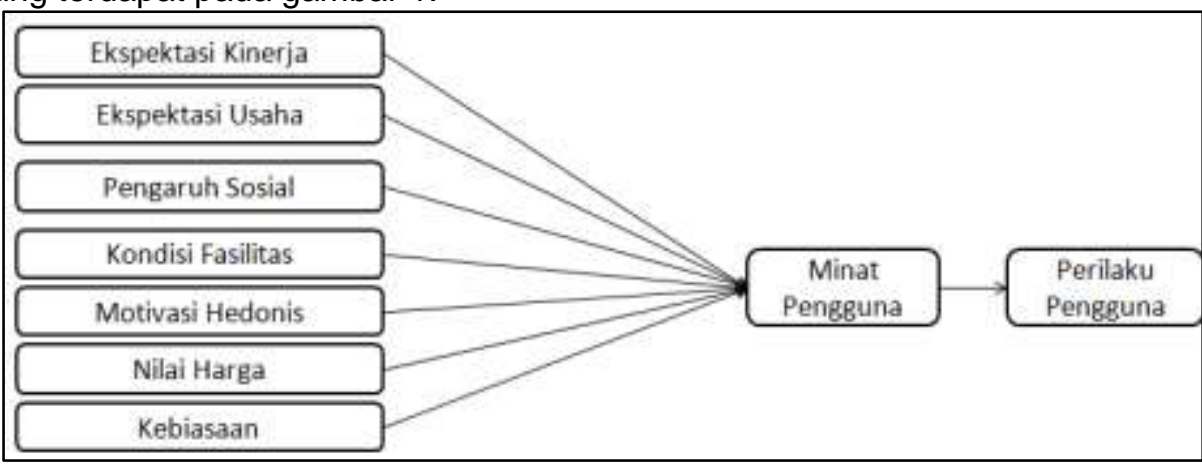

Gambar 1. Model UTAUT2

Keterangan hipotesis pada model UTAUT2 :

$\mathrm{H} 1$ : Ekspektasi kinerja memiliki pengaruh terhadap minat penggunaan aplikasi G-Meet

$\mathrm{H} 2$ : Ekspektasi usaha memiliki pengaruh terhadap minat penggunaan aplikasi G-Meet

H3 : Faktor sosial meiliki pengaruh terhadap minat penggunaan aplikasi G-Meet

$\mathrm{H} 4$ : Kondisi yang memfalitasi memiliki pengaruh terhadap minat penggunaan aplikasi G- Meet

H5 : Motivasi hedonis yang memiliki pengaruh terhadap minat penggunaan aplikasi G-Meet

H6 : Nilai harga memiliki pengaruh terhadap minat penggunaan aplikasi G-Meet

$\mathrm{H} 7$ : Kebiasaan memiliki pengaruh terhadap minat penggunaan aplikasi G-Meet

$\mathrm{H} 8$ : Minat penggunaan memiliki pengaruh terhadap perilaku pengguna

\subsection{Model Pengukuran Data}

Model pengukuran kualitas aplikasi dapat diukur dengan indikator pertanyaan dari masingmasing variabel, berikut adalah indikator yang dirancang pada kuesioner :

Tabel 1. Instrumen Penelitian

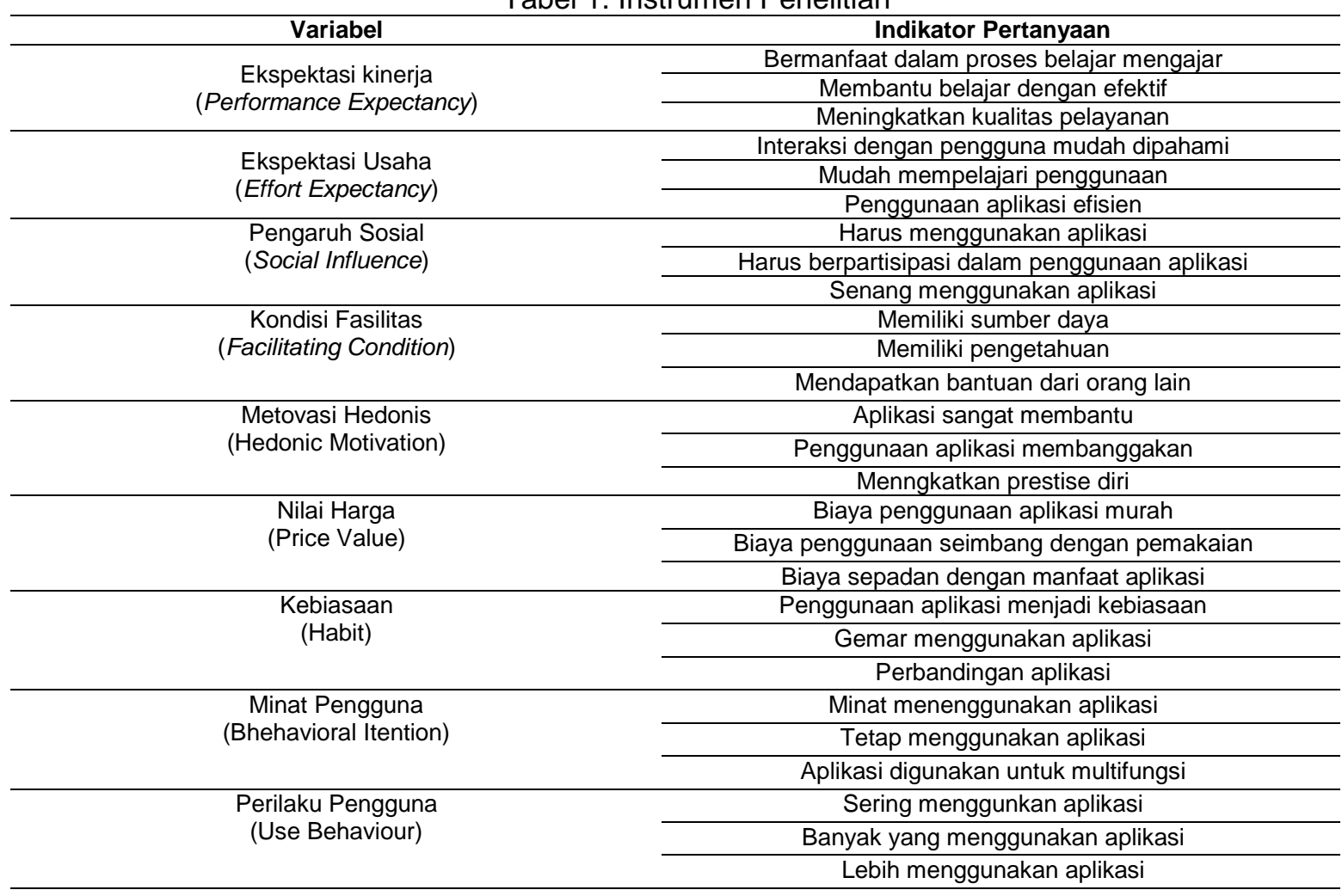


Berdasarkan kuesioner yang saat ini berhasil dikumpulkan berjumlah 125 responden, dimana jumlah responden tersebut sudah termasuk sampel dan populasi dari penelitian ini. Dalam penelitian ini mengubah penelitian kualitatif dengan menyebarkan lembaran kuesioner, sehingga data yang didapat dikonersikan menjadi data numerik dengan menggunakan Skala Likert.

Tabel 2. Skala Likert

\begin{tabular}{lll}
\hline No & Remaks & Score \\
\hline 1 & Sangat Setuju & 5 \\
\hline 2 & Setuju & 4 \\
\hline 3 & Netral & 3 \\
\hline 4 & Tidak Setuju & 2 \\
\hline 5 & Sangat Tidak Setuju & 1 \\
\hline
\end{tabular}

Pada prinsipnya, penelitian ini digunakan untuk membuat suatu persamaan yang kelak diharapkan dapat membantu pihak-pihak yang membutuhkan dalam memprediksi nilai variabel terkait dari variabel-variabel bebas didalam aplikasi tersebut.

\subsection{Hasil Pengumpulan Data}

Penyebaran kuesioner dilakukan sejak bulan Oktober 2020. Data kuesioner yang berhasil dikumpulkan berjumlah 125 responden dan data tersebut juga akan dianalisi lebih lanjut.

Responden dalam penelitian ini adalah mahasiswa STMIK Nusa Mandiri Jakarta. Berdasarkan data pada tabel 3 terdapat 88 responden berjenis kelamin laki - laki dan 37 responden berjenis kelamin perempuan. Sebagian besar responden berumur kurang dari 20 tahun berjumlah 33 responden, berumur 20 sampai 25 tahun berjumlah 73 responden, berumur 26 sampai 30 tahun berjumlah 6 responden, umur 31 sampai 35 tahun berjumlah 8 responden dan lebih dari umur 35 tahun berjumlah 5 responden. Status pekerjaan responden saat ini yaitu ada yang sudah bekerja sebanyak responden, yang belum bekerja sebanyak 66 responden, tidak bekerja sebanyak 49 responden dan lainnya terdapat 10 responden.

Tabel 3. Karakteristik Responde

\begin{tabular}{ccccc}
\hline No & Karakteristik & Keterangan & Jumlah & $\%$ \\
\hline \multirow{2}{*}{ Jenis Kelamin } & Laki-laki & 88 & $70,4 \%$ \\
\cline { 3 - 5 } & & Perempuan & 37 & $29,6 \%$ \\
\hline 2 & Usia & $<20$ & 33 & $26,4 \%$ \\
\hline & & $20-25$ & 73 & $58,4 \%$ \\
\hline & $26-30$ & 6 & $4,8 \%$ \\
\hline & & $31-35$ & 8 & $6,4 \%$ \\
\hline 3 & Status Pekerjaan & $>35$ & 5 & $4 \%$ \\
\hline & & Sudah Bekerja & 66 & $52,8 \%$ \\
\hline & & Belum Bekerja & 49 & $39,2 \%$ \\
\hline & & Lainnya & 10 & $8 \%$ \\
\hline
\end{tabular}

\section{HASIL DAN PEMBAHASAN}

\subsection{Pengujian Measurement Model}

Pada penelitian ini akan menguji hubungan antar variabel laten dengan indikator indikatornya atau pada outer model menjelaskan bagaimana setiap indikator berhubungan dengan variabel latennya. Terdapat beberapa tahapan pada pengujian outer model yaitu Avarage Variance Extracted (AVE), Komposit Reabialitas dan Cronbach Alpha. Nilai convergent validity adalah nilai faktor loading pada variabel laten dengan indikator - indikatornya. Nilai faktor loading yang diharapkan adalah > 0,7 namun jika nilai outer loading 0,5 masih dapat ditoleransi untuk diikutkan dalam model. Dan berikut ini merupakan model penelitian setelah nilai masing - masing indikator dimasukkan dan diproses menggunakan PLS Algorithm pada Gambar 2. 


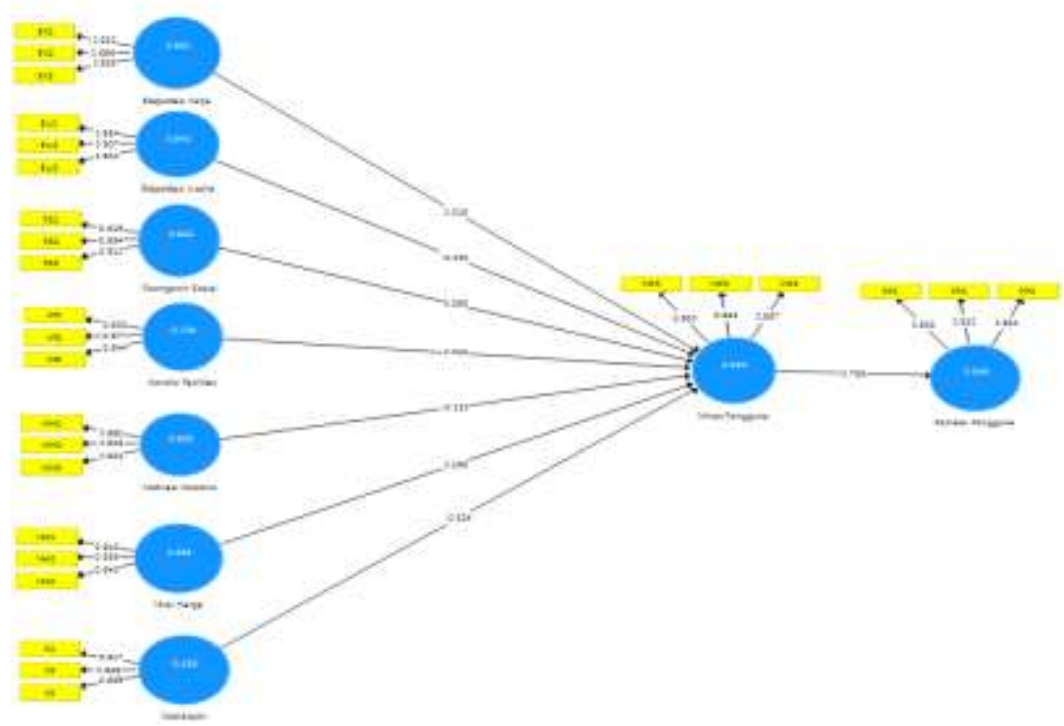

Gambar 2. Diagram Path Antar Variabel

Berdasarkan persepsi pengguna pengukuran ke tujuh konstruk di atas dapat disimpulkan bahwa nilai yang dihasilkan pada masing-masing indokator memiliki nilai outer loading $>7.0$. Hal ini berarti memberikan dampak yang positif bagi pengguna karena kemudahan dalam menggunakan aplikasi dan interaksi layanan yang baik dapat diperoleh pada aplikasi google meet. Suatu konstruk akan bernilai realibel jika mempunyai nilai AVE diatas 0,50 dan reabilitas komposit diatas 0,70 .

Tabel 4. Nilai AVE

\begin{tabular}{cc}
\hline Variabel & AVE \\
\hline Ekspektasi Kinerja & 0,881 \\
\hline Eksepektasi Usaha & 0,843 \\
\hline Perilaku Sosial & 0,822 \\
\hline Kondisi Fasilitas & 0,725 \\
\hline Motivasi Hedonis & 0,820 \\
\hline Nilai Harga & 0,885 \\
\hline Kebiasaan & 0,839 \\
\hline Minat Pengguna & 0,830 \\
\hline Perilaku Pengguna & 0,849
\end{tabular}

Pada tabel 4 hasil perhitungan nilai AVE bahwa semua variabel penelitian sudah sesuai dengan standar yaitu $>0,50$. Oleh karena itu tidak ada permasalahan dari model discriminant validity yang telah diuji atau sudah memenuhi sehingga dapat dilakukan pengujian selanjutnya.

Tabel 5. Nilai Reabilitas Komposit

\begin{tabular}{cc}
\hline Variabel & Reabilitas Komposit \\
\hline Ekspektasi Kinerja & 0,957 \\
\hline Eksepektasi Usaha & 0,942 \\
\hline Perilaku Sosial & 0,932 \\
\hline Kondisi Fasilitas & 0,888 \\
\hline Motivasi Hedonis & 0,932 \\
\hline Nilai Harga & 0,958 \\
\hline Kebiasaan & 0,940 \\
\hline Minat Pengguna & 0,936 \\
\hline Perilaku Pengguna & 0,944
\end{tabular}

Pada tabel 5 menunjukkan hasil perhitungan nilai reabilitas komposit, terlihat nilai reabilitas komposit untuk semua variabel atau dimensi sudah memiliki nilai $>0,70$. Dengan demikian model pengukuran di variabel tersebut memenuhi. Pengujian reliabilitas dari indikator penelitian dari setiap variabel diperkuat dengan pengujian cronbach alpha. Nilai cronbach's alpha yang baik diharapkan bernilai $>0,70$. Berikut adalah hasil dari perhitungan cronbach's alpha. 
IJSE - Indonesian Journal on Software Engineering, Vol.6, No.2, Desember 2020, 289-295 pISSN: 2461-0690 I elSSN: 2714-9935

Tabel 6. Nilai Cronbach's Alpha

\begin{tabular}{cc}
\hline Variabel & Cronbach's Alpha \\
\hline Ekspektasi Kinerja & 0,933 \\
\hline Eksepektasi Usaha & 0,907 \\
\hline Perilaku Sosial & 0,891 \\
\hline Kondisi Fasilitas & 0,811 \\
\hline Motivasi Hedonis & 0,890 \\
\hline Nilai Harga & 0,935 \\
\hline Kebiasaan & 0,904 \\
\hline Minat Pengguna & 0,897 \\
\hline Perilaku Pengguna & 0,911 \\
\hline
\end{tabular}

Pada tabel 6 dapat dilihat bahwa nilai cronbach's alpha semua variabel dalam penelitian sudah baik karena nilai cronbach's alpha $>0,70$. Hasil dari pengujian cronbach's alpha dapat disimpulkan bahwa model penelitian ini telah memenuhi uji reliabilitas sehingga dapat dilakukan pengujian selanjutnya.

\subsection{Pengujian Structural Model}

Pengujian inner model pada analisis Partial Least Square (PLS) dilakukan untuk mengetahui kesesuaian model dengan melihat dari nilai R square. Berdasarkan hasil pengolahan partial least square akan menghasilkan nilai koefisien determinasi ( $R$ square) pada variabel endogen, suatu model dikatakan kuat jika nilai $R$ square 0,75 , model moderat jika nilai $R$ square 0,50 dan model lemah jika nilai $R$ square 0,25 .

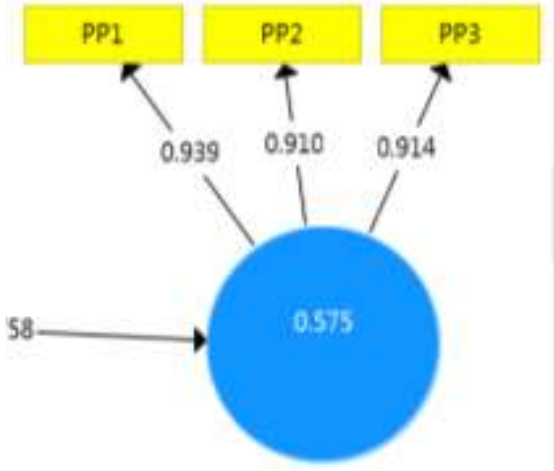

Gambar 3. Nilai R Square

Maka hasil dari gambar 3 diperoleh nilai $R$ square sebesar 0.575 , yang artinya nilai tersebut mengindikasikan bahwa perilaku pengguna dapat dijelaskan oleh variabel konstruk (ekspektasi kinerja, ekspektasi usaha, pengaruh sosial, kondisi fasilitas, motivasi hedonis, nilai harga, dan kebiasaan) sebesar $57,5 \%$ sedangkan sisanya $42,5 \%$ dipengaruhi oleh variabel lain yang tidak terdapat dalam model penelitian ini. Untuk mendapatkan uji hipotesis dan nilai path coefficient maka dilakukan pengujian dengan fungsi Bootstrapping. Berikut tabel 7 yang merupakan hasil dari T-statistik.

Tabel 7. Nilai T-Statistics

\begin{tabular}{cc}
\hline & T Statistik $(\mid$ O/STDEV $\mid)$ \\
\hline Ekspektasi Kinerja -> Minat Pengguna & 2.553 \\
\hline Ekspektasi Usaha -> Minat Pengguna & 0.195 \\
\hline Kebiasaan -> Minat Pengguna & 3.173 \\
\hline Kondisi Fasilitas -> Minat Pengguna & 0.542 \\
\hline Minat Pengguna -> Perilaku Pengguna & 15.966 \\
\hline Motivasi Hedonis - > Minat Pengguna & 1.144 \\
\hline Nilai Harga -> Minat Pengguna & 2.732 \\
\hline Peengaruh Sosial -> Minat Pengguna & 2.389 \\
\hline
\end{tabular}

Nilai coefficient path atau inner model menunjukan tingkat signifikansi dalam pengujian hipotesis. Signifikansi coefficient path ditunjukkan oleh nilai t-statistic harus di atas 1,64 untuk 
hipotesis pada alpha 5 persen. Sehingga variabel yang mempunyai hubungan yang signifikan ditunjukkan dalam tabel 7. Maka dari hasil penelitian ini berdasarkan nilai T-statistik di atas maka hipotesis yang diterima yaitu $\mathrm{H} 1, \mathrm{H} 3, \mathrm{H} 5, \mathrm{H} 7$, dan $\mathrm{H} 8$ sedangkan ketiga hipotesis lainnya tidak diterima karena tidak sesuai dengan persyaratan yang ada.

\section{KESIMPULAN}

Dari pengolahan data kuesioner sebanyak 125 responden dengan menggunakan software smartPLS maka dapat di ambil kesimpulan bahwa dalam pengujian measurement model yang dilalui dengan beberapa tahapan yaitu menghitung nilai AVE, menghitung nilai reabilitas komposit dan cronbach's alpha dapat diketahui bahwa nilai yang dihasilkan diatas nilai standar sehingga dapat dikatakan valid dan realibel akan data yang didapat. Selanjutnya, untuk pengujian structural model pada pengujian hipotesis, dapat dilihat dari nilai T_statistic yaitu diatas nilai 1,64 Maka dari hasil penelitian ini berdasarkan nilai T-statistik di atas maka hipotesis yang diterima yaitu $\mathrm{H} 1, \mathrm{H} 3$, $\mathrm{H} 5, \mathrm{H} 7$, dan $\mathrm{H} 8$ sedangkan ketiga hipotesis lainnya tidak diterima karena tidak sesusai dengan persyaratan yang ada.

\section{REFERENSI}

Afiana, F. N., Subarkah, P., \& Hidayat, A. K. (2019). Analisis Perbandingan Metode TAM dan Metode UTAUT2 dalam Mengukur Kesuksesan Penerapan SIMRS pada Rumah Sakit Wijaya Kusuma DKT Purwokerto. MATRIK: Jurnal Manajemen, Teknik Informatika Dan Rekayasa Komputer, 19(1), 17-26. https://doi.org/10.30812/matrik.v19i1.432

Auliya, N. (2018). Penerapan Model Unified Theory of Acceptance and, 1-10.

Fauzi, F. A., \& Lestari, P. (n.d.). Implementasi Pembelajaran Individual Head Number Berbasis Google Meet dan Classroom pada materi Trigonometri, 175-188.

Handayani, T., \& Sudiana, S. (2017). Analisis Penerapan Model Utaut (Unified Theory of Acceptance and Use of Technology) Terhadap Perilaku Pengguna Sistem Informasi (Studi Kasus: Sistem Informasi Akademik Pada Sttnas Yogyakarta). Angkasa: Jurnal Ilmiah Bidang Teknologi, 7(2), 165. https://doi.org/10.28989/angkasa.v7i2.159

Haris, C. A., WA, B. S., \& Nasiri, A. (2019). Penerapan Model Utaut2 Untuk Mengevaluasi Aplikasi Ruang Guru. Jurnal Teknologi Informasi, 3(2), 192. https://doi.org/10.36294/jurti.v3i2.1085

Kurniawan, A., Prabowo, G., \& Falahudin, T. (2020). Media Pembelajaran Berbasis Google Classroom. Auto Tech: Jurnal Pendidikan Teknik Otomotif Universitas Muhammadiyah Purworejo, 15(2), 97-108. https://doi.org/10.37729/autotech.v15i2.528

Mahande, R. D. (2018). UTAUT Model: Suatu Pendekatan Evaluasi Penerimaan E-Learning pada Program Pascasarjana. https://doi.org/10.31227/osf.io/254j7

Muhammad Taufik Hidayat, Qurrotul Aini, \& Elvi Fetrina. (2020). Penerimaan Pengguna E-Wallet Menggunakan UTAUT2 (Studi Kasus). Jurnal Nasional Teknik Elektro Dan Teknologi Informasi, 9(3), 239-247. https://doi.org/10.22146/.v9i3.227

Narayana, I. W. G. (2019). Analisis Penerapan Model UTAUT Terhadap Perilaku Pengguna ELearning (Studi Kasus : STMIK STIKOM Bali). Jurnal Teknologi Informasi Dan Komputer, 5(1), 158-164. https://doi.org/10.36002/jutik.v5i1.705

Radiansyah, E., \& Ariyanti, M. (2017). Analisis Pengaruh Penggunaan Tcash Menggunakan Unified Theory Of Acceptance And Use Of Technology 2 (utaut2) Studi Pada Mahasiswa Pengguna Tcash Di Universitas Telkom. EProceedings of Management, 4(1), 281-290.

Riadi, S., Normelani, E., Efendi, M., Safitri, I., \& Tsabita, G. F. I. (2020). Persepsi Mahasiswa Prodi S1 Geografi FISIP ULM Terhadap Kuliah Online Di Masa Pandemi Covid-19. PADARINGAN (Jurnal ..., 2(2), 219-227.

Rustaman, A. H. (2020). Efektivitas Penggunaan Aplikasi Daring, Video Conference Dan Sosial Media Pada Mata Kuliah Komputer Grafis 1 Di Masa Pandemi Covid-19. Jurnal IImu Sosial Dan Pendidikan, 4(3), 557-562.

Sadikin, A., \& Hamidah, A. (2020). Pembelajaran Daring di Tengah Wabah Covid-19. Biodik, 6(2), 109-119. https://doi.org/10.22437/bio.v6i2.9759

Sawitri, D. (2020). Penggunaan Google Meet Untuk Work From Home Di Era Pandemi Coronavirus Disease 2019 (Covid-19). Prioritas: Jurnal Pengabdian Kepada Masyarakat, 2(01), 13-21. Retrieved from https://jurnal.harapan.ac.id/index.php/Prioritas/article/view/161

Udayana, E. A. U. (2017). Penerapan Model Utaut2 Untuk Menjelaskan Minat Dan Perilaku Penggunaan Mobile Banking Di Kota Denpasar. E-Jurnal Akuntansi, 18(2), 1369-1397. 